\title{
Accelerator-based tritium facility to win out over rival US proposals...
}

Washington. Hazel O'Leary, the energy secretary, is about to endorse plans to build a \$3-billion particle accelerator designed to produce tritium for US nuclear weapons. Some physicists believe the accelerator could also be used for experiments initially planned for the now-abandoned Advanced Neutron Source.

In a long-awaited decision due to be announced within the next ten days, O'Leary is expected to reject proposals to build a nuclear reactor for tritium production. But she will recommend that the use of existing nuclear power stations for this purpose should be investigated as a back-up to the accelerator.

The accelerator decision will provide a critical boost for the Los Alamos National Laboratory in New Mexico, where a fouryear, \$300-million research and development programme - including the construction of a prototype - will be carried out as the project's initial stage.

The full accelerator would be built at one of the five candidate sites, including the Nevada test site and Savannah River, South Carolina, where O'Leary may make the announcement on a visit next week.

Tritium, the heaviest isotope of hydrogen, is a component of all the nuclear weapons the United States intends to retain. It decays with a half-life of 12 years, and since the closure of a previous facility at Savannah River in 1989 the United States has used spare tritium from weapons being taken out of service to replenish its stockpile.

But the Department of Defense insists that a source must be planned now to ensure supplies after 2011. O'Leary, concerned about accusations of being soft on defence issues, has promised Congress a formal decision on the technology and the site before November. She has always favoured the accelerator proposal, as it does not involve building a nuclear reactor.

O'Leary is likely to be strongly opposed by a powerful faction in Congress that backs the reactor alternative. Her decision to back the accelerator follows her receipt of a crucial report on the economics of tritium production prepared by an independent Washington consulting firm, Putnam Hayes and Bartlett (PHB).

The unpublished report found that using an existing civil reactor - probably at Plant Vogtle, near Savannah River - would be far cheaper than either construction proposal. Industry sources say that the report has forced O'Leary to consider the civil reactor option more closely, and that before making a final decision she must decide whether to pursue the civil reactor as a back-up to the accelerator or to research both options fully in a 'dual track' approach to the problem.

\section{...as German reactor faces concerns}

\begin{abstract}
Munich. Hazel O'Leary, the US energy secretary, has told the German authorities that she would prefer to see the controversial new research reactor FRMII converted to burning low-enriched uranium (LEU) fuel, rather than highly enriched uranium as currently planned.
\end{abstract}

But the letter, which reflects O'Leary's concern about the dangers of civilian trade in bomb-grade plutonium, is being played down by the State Department, apparently keen that the United States should not be seen to interfere with the domestic decisions of another country.

O'Leary's statement was made in a letter to Paul Leventhal, president of the private US Nuclear Control Institute. In reply to an enquiry about the US response to the FRMII, O'Leary wrote on 7 July that US efforts to enter the domestic debate in Germany over the reactor would be "potentially counterproductive". But she added that the United States "had expressed to
German authorities [the] hope that the FRMII will use only low enriched fuel".

O'Leary added that she had informed Gebhard Ziller, parliamentary state secretary for research, of US concern last September, and had "offered US assistance in redesigning the FRMII".

A spokesman for the Department of Energy (DoE) in Washington says the offer referred to meetings last year of German scientists with researchers from the Argonne National Laboratory who have experience in nuclear fuels of differing enrichment levels.

The DoE spokesman added that the discussions between Ziller and O'Leary had been informal, but also admitted that the State Department had not been happy with O'Leary's letter to Leventhal.

Gert von Hassel, a spokesman for the FRMII reactor programme, says that O'Leary's letter is not an "official diplomatic protest". Despite continuing protest, construction of the reactor is due to start next year.
The use of a civil reactor for military tritium production would conflict with the traditional separation of military and civil nuclear work in the United States, and despite its immense cost - the construction of a brand-new facility has heavyweight political support.

O'Leary and other friends of the national laboratories, led by Senator Pete Domenici (Republican, New Mexico), want an accelerator. By contrast, a new reactor, which would cost up to $\$ 6$ billion and would also probably be built at Savannah River, is supported by Strom Thurmond (Republican, South Carolina), chair of the Senate Armed Services committee, and Floyd Spence (Republican, South Carolina), chair of the House of Representatives National Security committee.

The reactor is seen by the nuclear industry as its last and best chance of building a nuclear plant in the United States - the first for 15 years. But its supporters received a setback last month, when an attempt by Spence's committee to by-pass the Depart-

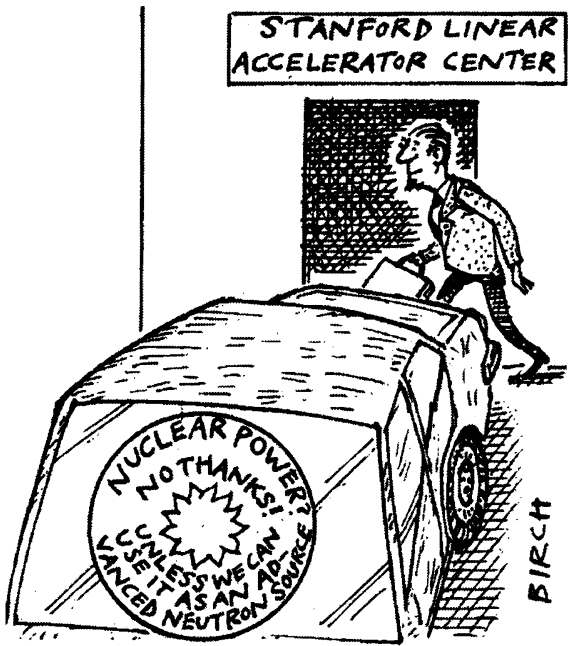

ment of Energy (DOE) and spend $\$ 100$ million on the reactor was attacked as an 'earmark', and defeated on the House floor.

O'Leary was briefed last week on the PHB report, which argues billions of dollars could be saved if the government either paid an electricity utility company to make the tritium in existing plant or purchased an existing power plant outright to produce it.

At the same time, a number of observers, including supporters of the nuclear weapons programme, believe that the tritium facility is entirely unnecessary. According to one former senior official of the Bush administration, there is "no national security need" for the facility, as present stocks will arm thousands of weapons for decades to come, and extra supplies can be obtained from 